\title{
Application effect of biocide SW303 in seawater recirculating cooling system
}

\author{
Yahong $\mathrm{Li}^{\mathrm{a}}$, Zheng Zhou ${ }^{\mathrm{b}}$, Xiaofang Zhao ${ }^{\mathrm{c}}$ \\ ${ }^{1}$ The institute of Seawater Desalination and Multipurpose Utilization, SOA, Tianjin 300192, Chin \\ aflyllyh@163.com, btjtgzyyx@126.com, cwzyy04690423@sina.com
}

Keywords: biocide, SW303, concentrated seawater, recirculating cooling, bacteria

\begin{abstract}
This paper is to present our research results of the efficacy of SW303 in term of inhibiting bacteria growth in concentrated seawater and under the process conditions of seawater recirculating cooling system through the rotating specimen test and the dynamic simulation experiments. For our research purpose, two kinds of concentrated seawater were used as the test solution and carbon steel was choosed as the test material. Two sets of device simulating seawater recirculating cooling system were used for study of the adding cycle of SW303. This research has focused on the inhibiting effect of SW303 on the growth of the heterotrophic bacteria and iron bacteria through determination of the bacterial count, corrosion rate of test specimen and total iron content, with the plate count method for heterotrophic bacteria, the most-probable-number(MPN) method for iron bacteria, the weight loss method for analysis of SW303 corrosivity to carbon steel, and the rotating specimen method and the dynamic simulation experiment to simulate the process conditions of seawater recirculating cooling system. The results of our research indicate that $2.5 \mathrm{mg} / \mathrm{L}$ of non-oxidative biocide $\mathrm{SW} 303$ could efficiently inhibit the growth of heterotrophic bacteria and iron bacteria in two times of concendated seawater. And SW303 could inhibit the corrosion of carbon steel efficiently by the function of killing bacteria and was compatible well with corrosion and scale inhibitor. The results of dynamic simulation experiments showed that SW303 can well inhibit the growth of heterotrophic bacteria and iron bacteria in the simulating process of seawater recirculating cooling system. Though the effect of inhibiting the growth of iron bacteria was not ideal in $1 \#$ system, the iron bacterial count could be inhibited near the control index in $2 \#$ system through shortening the adding cycle of SW303. Moreover, concentration time of seawater did not affect the efficacy of biocide SW303. Thus the main factors affecting the efficacy of SW303 included the concentration and interval time of adding SW303 in the simulating process of seawater recirculating cooling system. Large dose and short adding cycle were advantageous for SW303 to inhibit the growth of heterotrophic bacteria and iron bacteria in the concentrated seawater and the process simulating seawater recirculating cooling system. When there was a litter many of iron bacterial count in the test solution and making-up seawater, it was necessary for designing dose method of SW303 to consider comprehensively the inhibiting effect over two classes of bacteria, especially iron bacteria.
\end{abstract}

\section{Introduction}

Seawater recirculating cooling technology was developed on the basis of fresh water recirculating cooling and one-through seawater cooling technique. The technology of seawater recirculating cooling was advantage of water saving, environmental protection and low engineering investment and operating cost. Recently it was applied in the cooling engineering in the coastal industry, especially in chemical engineering and electric power industry ${ }^{[1-4]}$. Its technological process was as follows: natural seawater without treatment was flowed through cooling tower for cooling again after used to cooling heat exchanger. The process was constantly circulating. Seawater was recycled and concentrated in the process. In the cooling system, the heat exchanger was made of metal generally. It was easy for metal to be corroded in seawater. Because biological corrosion was a typical corrosion of carbon steel in seawater, biocides were widely used in seawater cooling engineering. However many kinds of metal was easily corroded by oxidizing biocides. It was important to develop and 
screen non-oxidizing biocides suitable to seawater in order to develop and apply seawater cooling technology in chemical engineering industry.

Biocide SW303 is an organosulfur compound ${ }^{[5]}$ and low-toxic whose $\mathrm{LD}_{50}$ to rat is only $3000 \mathrm{mg} / \mathrm{kg}$. Moreover, it is easily degraded to no toxic and has no accumulated toxicity in water, which is an eco-friendly non-oxidative biocide. SW303 has been used as biocide in the overseas water treatment industrial early in 1970's, but just recently used in China. At present, studies on the preparation, analysis, behavior and application of SW303 are mostly focused on fresh water cooling system, however, the paper will put stress upon research on its application for seawater recirculating cooling system.

\section{Material and methods}

\section{Material.}

Biocide SW303 was synthesized in our lab. All corrosion specimen was made of A3 carbon steel with standard type of $50 \mathrm{~mm} \times 25 \mathrm{~mm} \times 2 \mathrm{~mm}$ and purchased from Yangzhou keguang Ltd., Jiangsu. Seawater used in the test was provided by Tanggu seawater purifying treatment plant, Tianjin. Seawater was drawn from Bohai bay and simply handled by sedimentation and sand filtration in the plant. Seawater quality in the tests was listed in table1.

Table1. Seawater quality in the tests

\begin{tabular}{lc}
\hline \multicolumn{1}{c}{ Item } & Quality of seawater \\
\hline $\mathrm{pH}$ & 7.84 \\
Turbidity [NTU] & 8.1 \\
Total alkalinity $[\mathrm{mg} / \mathrm{L}]$ & 99.26 \\
Conductivity $[\mu \mathrm{S} / \mathrm{cm}]$ & 37600 \\
$\mathrm{Cl}^{-}[\mathrm{mg} / \mathrm{L}]$ & 13134.65 \\
$\mathrm{Ca}^{2+}[\mathrm{mg} / \mathrm{L}]$ & 276.15 \\
$\mathrm{Mg}^{2+}[\mathrm{mg} / \mathrm{L}]$ & 889.02 \\
$\mathrm{SO}_{4}{ }^{2-}[\mathrm{mg} / \mathrm{L}]$ & 1832.82 \\
\hline
\end{tabular}

\section{Test solutions.}

The test medium was two to three times concentrated seawater with the phosphorous-kind corrosion and polyacrylic acid scale inhibitor, which was prepared by seawater through vaporization concentration for about $120 \mathrm{~h}$ under $50{ }^{\circ} \mathrm{C}$. The concentration cycle of the test medium was calculated in term of chloride ion concentration in seawater. $\mathrm{pH}$ of the concentrated seawater was natural balance without any treatment.

\section{Test specimen.}

The test specimen was corrosion specimen by pre-filmed under $30{ }^{\circ} \mathrm{C}$ for $48 \mathrm{~h}$ after cleaned.

\section{Test procedure.}

The rotating specimen test was carried out in accordance with GB/T 18175-2000 Determination of corrosion inhibition performance of water treatment agents-Rotating specimen method and ASTM G31-72(2004) Standard practice for laboratory immersion corrosion testing of metals. There were two stages in the whole experimental period, including concentrating and natural stage. The test was set as the control group and experimental group. Seawater without SW303 and with $2.5 \mathrm{mg} / \mathrm{L}$ of SW303 was used in the control group and experimental group respectively. Aliquots of $2 \mathrm{~L}$ seawater were distributed into each $2 \mathrm{~L}$ glass beaker and kept under $50^{\circ} \mathrm{C}$. After about $120 \mathrm{~h}$ of concentrating stage, it was concentrated to $1 \mathrm{~L}$ of the test solution through natural evaporation. The concentration of the test solution was maintained through quantitatively adding distilled water during $72 \mathrm{~h}$ of natural stage. The volume of adding distilled water was equal to the vaporization loss. The test specimen was hanged into the test solution and rotated at a rate of about $80 \mathrm{r} / \mathrm{min}$.

The dynamic simulation experiment was carried out in accordance with HG/T 2160-2008 Dynamic simulation method for cooling water. The operation parameters of test simulated the seawater recirculating cooling system of chemical engineering industry. The test solution included two to three times concentrated seawater. The concentration of the test solution was controlled 
through continuously making up and discharging water. The amount of makeup water was the sum of the vaporization losses and blowdown losses. The water capacity of the device was about $180 \mathrm{~L}$. The flow rate of recirculating water was $800 \mathrm{~m}^{3} / \mathrm{h}$. The outlet temperature of the heat exchanger was generally lower $9^{\circ} \mathrm{C} \sim 11^{\circ} \mathrm{C}$ than inlet. The running time of experiment was $480 \mathrm{~h}$.

The total number of bacteria was timely assayed in process of above two kinds of test in accordance with GB/T 14643.1-2008, GB/T 14643.5-2008and GB/T 14643.6-2008. Corrosion rate of test specimen was determined by the weightlessness method after the experiments.

\section{Results and discussion}

\section{Efficacy of SW303 on bacteria in the rotating specimen test.}

The result of the rotating specimen test indicated that $2.5 \mathrm{mg} / \mathrm{L}$ of SW303 can efficiently inhibit grow-up of heterotrophic bacteria and iron bacteria in two times concentrated seawater(see Fig. 1). When exposed to the new environment, bacteria generally go through a period of delay without obvious change of the quantity. However, at the beginning of the test, the total bacteria count in the control group was reduced by above $30 \%$ because of the effect of temperature. The temperature is about $20^{\circ} \mathrm{C}$ to $25^{\circ} \mathrm{C}$ suitable to most of marine bacteria growth. When exposed to $50^{\circ} \mathrm{C}$, a part of marine bacteria could die due to unable to tolerate to high temperature, which resulted in the decrease in the number of bacteria at the start. The count of bacteria had been increased in the control group since bacteria was suitable to the temperature of the test solution. Because of combined action of high temperature and the killing bacteria efficacy of SW303, the quantity of bacteria was decreased sharply by above $70 \%$ in the experimental group at the start of concentrating stage. It was more effective and long-acting of SW303 on iron bacteria than on heterotrophic bacteria. Through about $160 \mathrm{~h}$ of stable phase, the quantity of heterotrophic bacteria showed an ascending trend during 168 $\mathrm{h} \sim 192 \mathrm{~h}$, but the quantity of iron bacteria still remained stable.

After SW303 was consumed completely in the test solution, it would lost the killing bacteria efficacy, and the number of bacteria in the test solution should be increasing because of the growth and reproduction of the survival bacteria. If there was no bacteria survival, the number of bacteria would keep stability. During the period of test, SW303 and seawater was not supplemented. Ever if there was a small amount of bacteria in air added in the test solution due to stirring, the number of bacteria would not increase obviously in the test solution without survival bacteria and residue of SW303. Bacteria in air needed time to adapt to the test solution and proliferation was not so fast. The half-life of SW303 was $26 \mathrm{~h}^{[6]}$. Its degradation could fit to a first-order kinetic model $\left(\ln \left(c_{t} / c_{0}\right)=-0.02666 t\right)$. Thus no SW303 was residual after $192 \mathrm{~h}$ in the test solution. It was obvious to heterotrophic bacteria that there was bacteria survival after $192 \mathrm{~h}$ of operation, while iron bacteria were killed completely by SW303 after $192 \mathrm{~h}$.
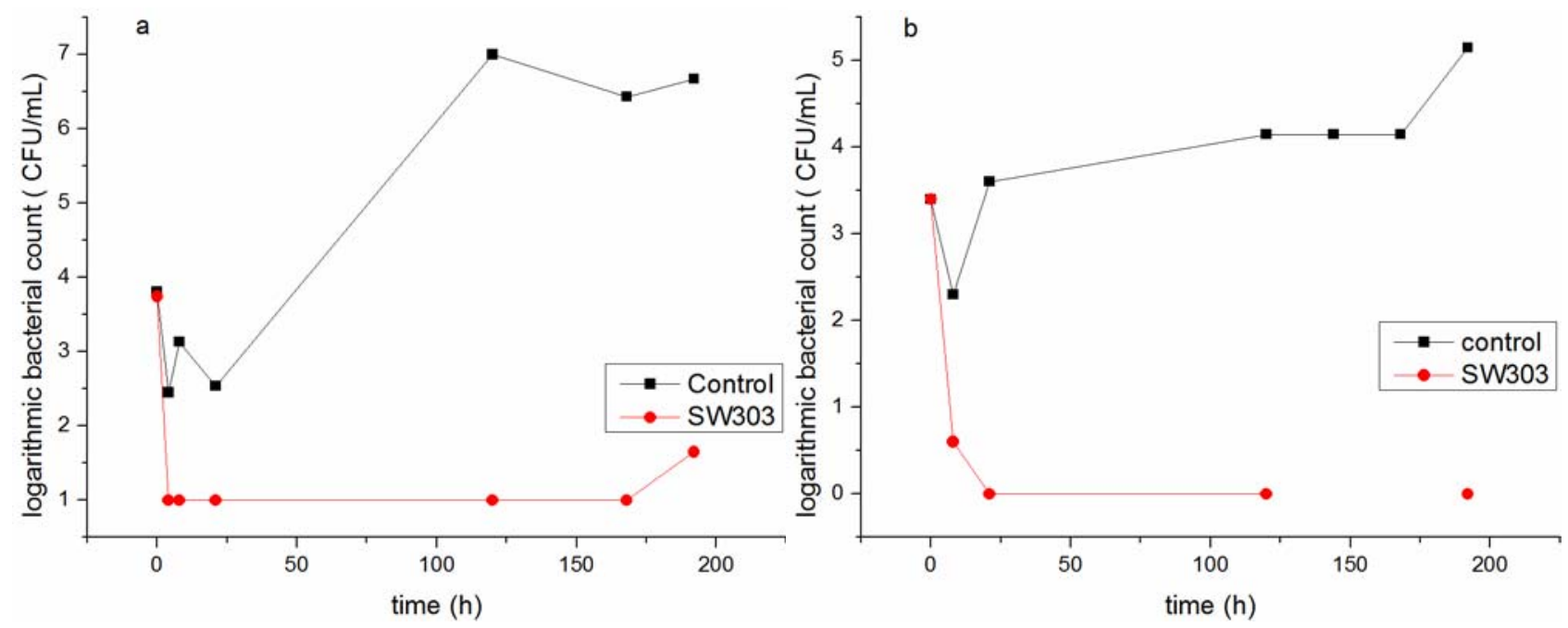

Figure 1. Inhibition effect of SW303 on bacteria in the rotating specimen test(a:heterotrophic bacteria, b:iron bacteria) 


\section{Corrosivity efficacy of SW303 to test specimen of carbon steel.}

Because the phosphorous-kind corrosion inhibitor was used in the test, the corrosion rate of test specimen was below $0.015 \mathrm{~mm} / \mathrm{a}$ in two groups of test, lower than the standard corrosion rate of 0.075 $\mathrm{mm} / \mathrm{a}$ in seawater. The corrosion rate in the control group was about 2.1 times as many as the experimental group(see fig. 2). SW303 was effective on inhibiting corrosion of carbon steel ${ }^{[7]}$.It is well known that carbon steel would be corroded in seawater by both seawater quality and microbiological induced corrosion. When bacteria were killed by SW303 in test solution, microbiological induced corrosion was weakened on the test specimen.

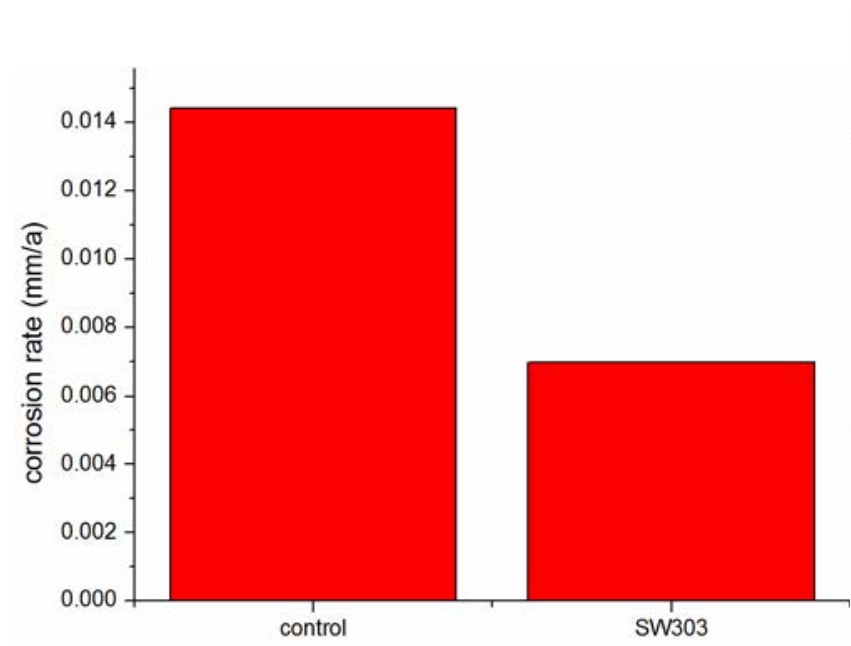

Figure 2. Corrosion rate of test specimen

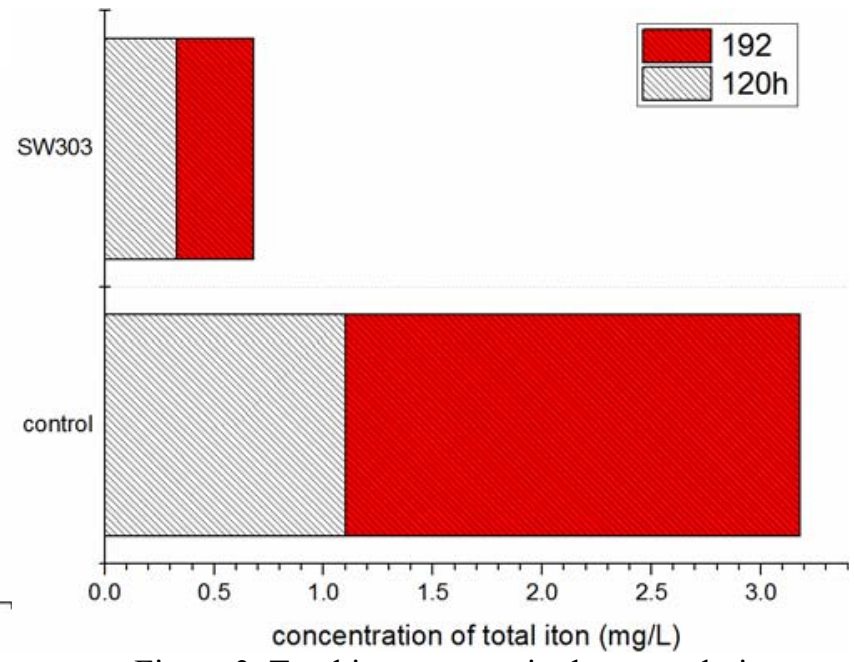

Figure 3. Total iron content in the test solution

Total iron content in the test solution was affected by corrosion condition of carbon steel in the rotating specimen test. If specimens were corroded, ferric ion would released from the carbon steel surface into the test solution. Finally, the total iron content would increase in the solution. After 120 $\mathrm{h}$ of concentrating operation, the total iron content of the control group was $70 \%$ more than the experimental group. Furthermore, it continuously increased at a higher rate within $72 \mathrm{~h}$ of normal running, while the total iron content kept on a stead value of $3.33 \mathrm{mg} / \mathrm{L}$ in the experimental group(see fig. 3). The results indicated that corrosion condition of the test specimen in the control group was worse than the experimental group and adding SW303 in seawater could lighten and inhibit the corrosion of carbon steel efficiently.

\section{Efficacy of SW303 in the dynamic simulation experiments.}

Heat changer in cooling systems of chemical engineering industry was mostly made from carbon steel which was bad resistance to seawater corrosion. Because biological corrosion was a typical corrosion of carbon steel in seawater, biocides were widely used in seawater cooling engineering. However carbon steel was easily corroded by oxidizing biocides. It was important to develop and screen non-oxidizing biocides suitable to seawater in order to develop and apply seawater cooling technology in chemical engineering industry.

Two sets of device were used in the test, which were made by simulating the seawater recirculating cooling system of chemical engineering industry. One was named by $1 \#$ system with 2 times concentrated seawater and the other was $2 \#$ system with 2.5 times concentrated seawater. SW303 was added by the impactor method in 1\# system every 72 hours and in $2 \#$ system every 48 hours. The adding concentration of SW303 was decreased gradually(see fig. 4) . 


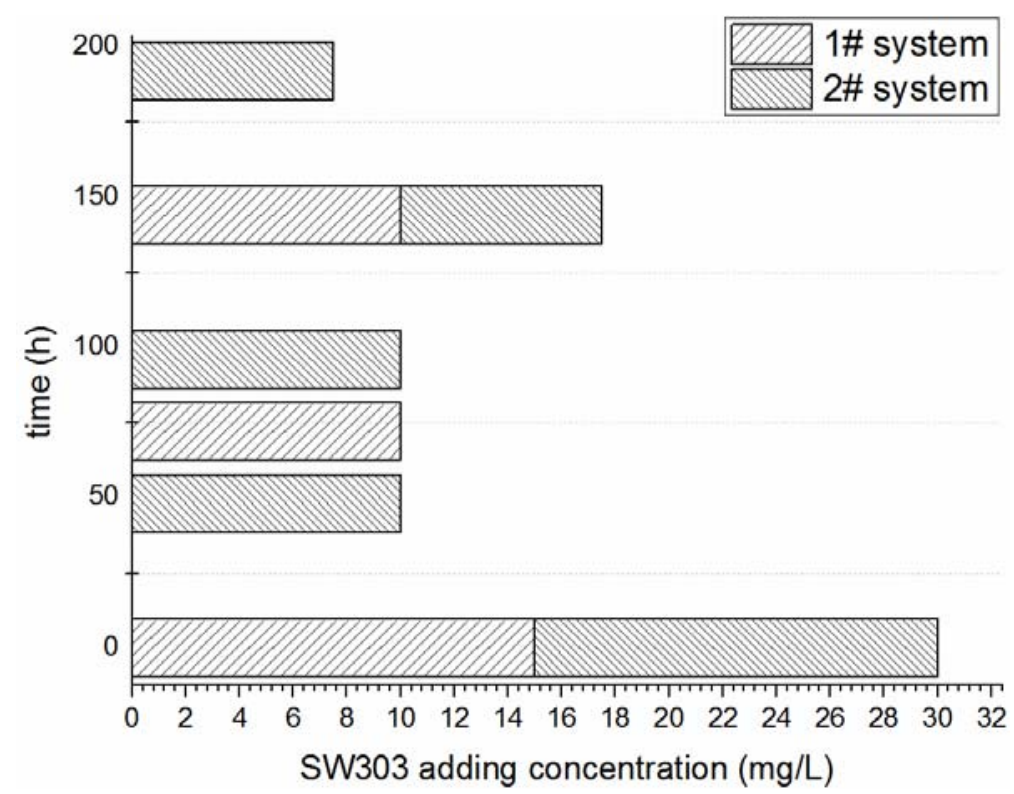

Figure 4. Adding concentration and time of SW303 in two sets of device

It was obvious that SW303 could inhibit the bacterial growth in two dynamic simulation experiments. Concentration cycle of seawater did not affect the efficacy of biocide SW303. Though the adding concentration of SW303 in 1\# system was as more as in 2\# system, the bacterial count was more in $1 \#$ system than in 2\# system. It might be because the time interval of SW303 adding was longer in $1 \#$ system than in 2\# system, which indicated the important of adding time for efficacy of inhibiting bacterial growth of biocides. The bacterial count was stable in the making-up seawater during the test period. The change trend of the bacterial count was consistent with adding time of SW303, that decreased immediately with adding of SW303 and came to increasing during the period of stopping dose. After $240 \mathrm{~h}$ of running, there was no any biocide to be added in $2 \#$ system. And the bacterial growth was still inhibited efficiently within next $120 \mathrm{~h}$ though the bacterial count was growing gradually. It showed that SW303 could inhibit bacterial growth for a relatively long period.

In the dynamic simulation experiments, the heterotrophic bacterial count could be inhibited efficiently below the control index of $500,000 \mathrm{CFU} / \mathrm{mL}$ in accordance with $\mathrm{GB} / \mathrm{T} 23248-2009$ by SW303. However, the iron bacterial count often exceeded the control index of $300 \mathrm{strain} / \mathrm{mL}$ in $1 \#$ system. And the iron bacterial count could be inhibited near the control index in 2\# system during dosing cycle of 10 days, which was gradually beyond the control index after stopping adding SW303. It is easily concluded that the effect of short adding cycle was really better. Furthermore, it seemed that SW303 was more efficient on heterotrophic bacteria than iron bacteria in the dynamic simulation experiments, which was different from the results of the rotating specimen test. When the bacterial count in making-up seawater was in a same magnitude, but the control index of iron bacteria was three orders of magnitude lower than its of heterotrophic bacteria, it was clear that there was more difficult for iron bacteria to be inhibited efficiently below the control index under the same amount of SW303. In fact, the number of iron bacteria was far less than its of heterotrophic bacteria in the natural seawater. Thus, the growth of iron bacteria could be inhibited efficiently in the seawater recirculating cooling engineering. 

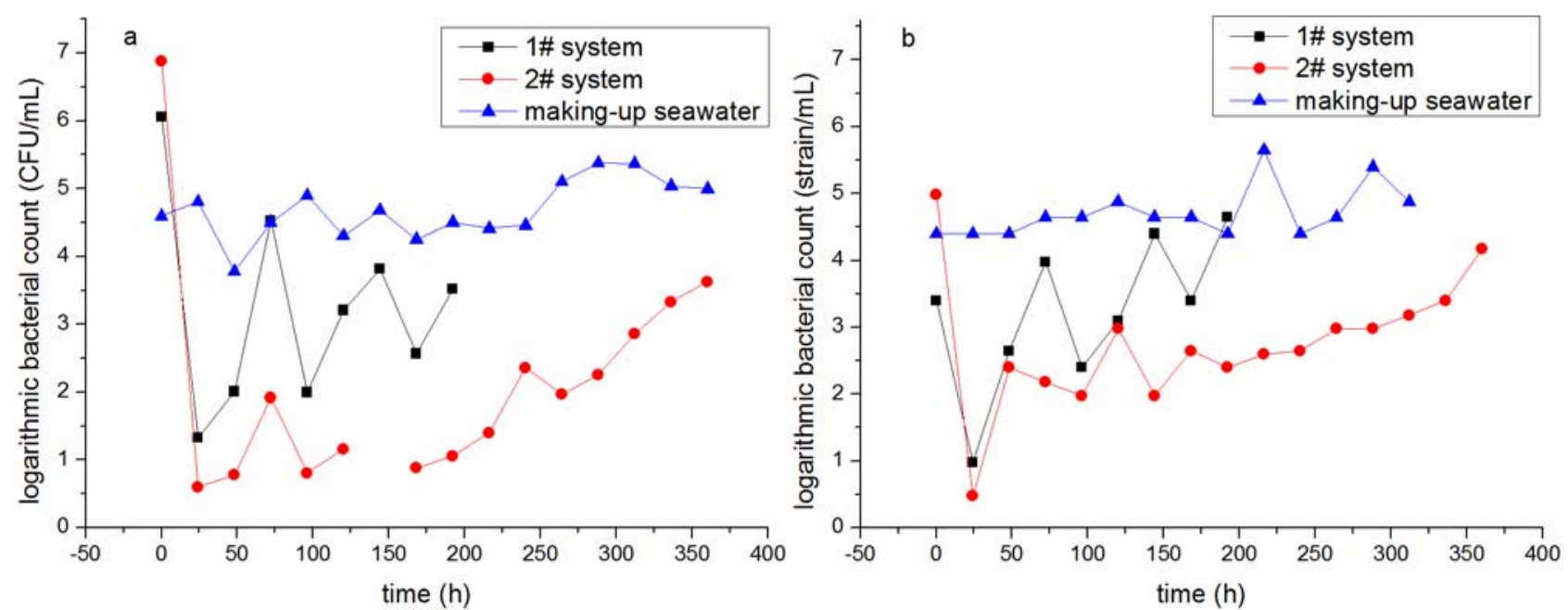

Figure 5. Inhibition effect of SW303 on bacteria in the dynamic simulation experiments(a:heterotrophic bacteria, b:iron bacteria)

\section{Conclusion}

SW303 is a wide-spectrum biocide, which can kill many species of bacteria. Heterotrophic bacteria and iron bacteria are two classes of typical bacteria in recirculating cooling water. SW303 could inhibit their growth efficiently in concentrated seawater and under the process conditions of seawater recirculating cooling system. Though the results of inhibiting the iron bacterial growth was not so well in the dynamic simulation experiments, there was still a fact that the inhibiting bacteria effect of short adding cycle was really better than long cycle. Concentration cycle of seawater did not affect the efficacy of biocide SW303. Moreover, SW303 was effective on inhibiting corrosion of carbon steel through killing bacteria and weakening microbiological induced corrosion.

\section{References}

[1] Jopp, C. K. Construction and operation of Rostock coal-fired power plant. International power, 1997,1(1):31-33.

[2] Rattan Tawney, Zahid Khan, Justin Zachary. Economic and Performance Evaluation of Heat Sink Options in Combined Cycle Applications. Journal of Engineering for Gas Turbines and Power,2005,127(2):397-403.

[3] Mostafa H. Sharqawy, Syed M. Zubair, and John H. Lienhard. On Thermal Performance of Seawater Cooling Towers[J]. Journal of Engineering for Gas Turbines and Power,2011,133(4):7

[4] W.C. Zhao. Seawater recirculating cooling technology of Chine reaching the international advanced level. Generating equpment, 2008,22(3):240

[5] C. Chen, C.Y. Hou, Y.H. Li, et al. Study on attenuation pattern of biocide SW303 in seawater, Technology of water treatment, 2007,33(12):58-61.

[6] Y.H. Li, H. Yuan, X.F. Zhao, et al. Calculation of biocide's discharge source intensity in recirculating cooling water at a power plant, Water Supply And Drainage,2015,41:237-240.

[7] Y.H. Li, H. Yuan, J. Wang, et al. Precision Analysis of Rotary Hanging Pieces Method for Measuring Corrosion Inhibition Performance of Water Treatment Agent, Corrosion and protection, 2015,35(7):664-668. 